\title{
Asset Scale and Capital Structure on The Performance of Sharia Banks
}

\author{
Rizky Windar Amelia and Cahaya Nugrahani \\ Tax Management, Faculty of Economics \\ University of Widya Dharma Klaten \\ Jl. Ki Hajar Dewantara, Klaten, 57438, Indonesia
}

\section{Info Article}

History article:

Approved: 8 December 2018

Published: 25 December 2018

Keywords:

Bank performance; Capital structure; Commercial banks; Operation scale; Sharia BPR

ISSN (print) : 2598-7763

ISSN (online): 2598-7771

\begin{abstract}
Abtract
The purpose of this study is to examine the effect of operation scale and capital structure on the performance of Sharia Banks - Sharia Business Units and Sharia BPR in Central Java and Yogyakarta Special Region. The level of performance is obtained through annual publication financial report in which the banking health ratio is measured through the criteria regulated by Bank Indonesia using five aspects of CAMEL, capital adequacy ratio, asset quality, management, earning, and liquidity aspects. The number of bank samples studied consisted of 15 sharia banks, sharia business units and 19 Sharia BPRs in Central Java and Yogyakarta Special Region using financial statements on December 31, 2015. The model tests were carried out using Pearson Product Moment and One-Way ANOVA tests. The test results explain there is a significant influence between the asset scale and capital structure on the performance of sharia banking operations.
\end{abstract}

Citation: Amelia, Rizky Windar dan Nugrahani, Cahaya. (2018). Asset and Capital Structure on The Performance of Sharia Banks. Accounting and Financial Review, 1 (2)

\begin{abstract}
Abstraks
Tujuan dari penelitian ini adalah untuk menguji pengaruh skala operasi dan struktur modal terhadap kinerja Bank Syariah - Unit Bisnis Syariah dan BPR Syariah di Jawa Tengah dan Daerah Istimewa Yogyakarta. Tingkat kinerja diperoleh melalui laporan keuangan publikasi tahunan, di mana rasio kesehatan perbankan diukur dengan kriteria yang diatur oleh Bank Indonesia menggunakan lima aspek CAMEL, rasio kecukupan modal, kualitas aset, manajemen, pendapatan, dan aspek likuiditas. Jumlah sampel bank yang diteliti terdiri dari 15 bank syariah, unit bisnis syariah, dan 19 BPR Syariah di Jawa Tengah dan Daerah Istimewa Yogyakarta menggunakan laporan keuangan pada tanggal 31 Desember 2015. Model tes dilakukan dengan menggunakan Pearson Product Moment dan One-Way ANOVA tes. Hasil pengujian menunjukkan skala aset dan struktur modal berpengaruh terhadap kinerja operasi perbankan syariah
\end{abstract}

$\triangle$ Corresponding Author: Rizky Windar Amelia Tel. /Fax : +6282138230183

E-mail: windar_11@yahoo.co.id
JEL Classification: G21, G32, G33

DOI: https://doi.org/10.26905/afr.v1i2.2789

\section{INTRODUCTION}

Islamic religious movements through a large demonstration in the competition of DKI Regional Election erupted in December 2016. At that time, some Muslim leaders expressed their planning in establishing Sharia Banks 212. However, this noble good intention needs to be studied carefully. If this notion is just based on a passionate emotion, the desire to establish an Islamic bank is like a dream. Banking business governance needs to be taken into account. The reason is because it has to be managed well and established with a strong Islamic background, however nowadays there are a num- 
ber of sharia banks having quite bad reputation, there are even three sharia banks that have loan problems above $10 \%$ (www.ojk.go.id).

The Islamic capital adequacy ratio needs to be increased. In the end, the government implemented a new policy regarding the capital calculation called as CKPN (Reserve for Impairment Losses) in which in the past two years has followed conventional banking policies. This resulted in additional provisions which caused the decreasing profitability of sharia banks. Some sharia banks end up with lack of capital adequacy ratios.

The market share of the sharia banking industry has never touched 5 percent, so that the term "five percent traps" is created. The cause comes from the sharia banking industry itself and general economic conditions. Indonesian sharia banking industry is in the condition of a high concentrated oligopoly market structure (Sancoko, 2012). On the other hand, there are two banks having the largest market share of almost 60 percent, so that if there is a slowdown in the two largest banks, general sharia banking industry will also slow down. These two sharia banks over the past two years have experienced a slowdown in asset growth due to the impact of internal sharia banking policies by continuing to improve the quality of financing and the impact of sharia banks that restrain the excess liquidity experienced by sharia banking in the past two years (www.ojk.go. id).

Meanwhile, the growth rate of sharia banking in five years which reached 40 percent to 60 percent has exceeded the engine of sharia banks to continue to grow. The impact is an increase in nonperforming finance reaching 5.68 percent, this is beyond the limit tolerated by the Financial Services Authority (OJK) at 5 percent. The growth of sharia banks based on Indonesian Banking Statistics data began to decline in the 2014 period due to the impact of the world crisis. The amount of financing disbursed and third-party funds of sharia banking has decreased, thus it impacts on the declining asset growth and profitability of sharia banks. The declining performance of sharia banks is also indicated by a decrease in liquidity and an increasing spending of sharia bank (Syafrida and Aminah, 2015).

Sharia banking development potential still presents as Indonesia has a large Muslim population, so it is actually a fertile ground for the development of Sharia banking as part of the Sharia economic system. The Sharia banks in Indonesia only manage public funds around IDR 240 trillion from a total of IDR 2000 trillion. Bank customers who are interested in Sharia banks are only 14 percent, a very small percentage compared to the Muslim population in the country. This problem arises because there is still a lack of socialization of Sharia banks including the employees having a majority of conventional banking education background, the not optimal synchronization of policies between institutions, as well as regulatory support and the derivatives in the field of Sharia economics which have not been satisfactory (Ardiansyah et. al., 2013).

Currently in Indonesia, there are many developing sharia financial institutions in the society. It is ideally aimed at serving Muslim consumers in Indonesia, in which based on the 2010 census results show that Indonesian Muslim population is $87.18 \%$ of the total population of Indonesia. But in fact, the use of sharia financial services or products in Indonesia is still low compared to the number of Muslim populations that exists. This is due to the low level of financial literacy of the consumers towards Islamic/ sharia finance (Yulianto, 2018). This was also proved from OJK National Financial Literacy Survey in 2013, showing the population literacy of national financial services was only $22 \%$ of Indonesia's population who understood banking services.

The Financial Services Authority also stated that one of the obstacles in the development of sharia banking was the low level of public trust in the non-conventional institutions. There are even Muslim scientists who criticized sharia banking, they argue that sharia banks in carrying out their transactions are in the contrary to the concept ( $\mathrm{Mu}^{\prime}$ allim, 2003). Acording to Remy (1999) the observations or research of several Islamic scientists state that sharia banks in carrying out their business activities, in fact, do not exclude interest and share risk, but maintain the practice of charging interest. In other words, avoid risk in a cunning way.

From the description above, sharia banking is obliged to manage its business with prudential principles and good governance so that the risks of its business are managed. Increasing institutional resilience and creating a sound banking system and being able to compete nationally and internationally can increase the bank's ability to face risks caused by crisis conditions and the growth of banking business through increasing capital quality and quantity according to risk profiles that serve as buffers if financial and economic crises occur which can disrupt financial system stability (Setiawan and Sari, 2018).

The next challenge for sharia banking is to 
take into account the scale of operations (competition in collecting customer funds). Third party fund for banks is like blood, so that without it, banking institutions will be sluggish. Therefore, sharia banks must be able to dig and get cheap funds. So far, sharia banking has a low composition in the matter of low-cost funds, such as wadiah demand deposits.

Bank as a trusted institution, in its operation also functions as a public service that strives with public funds. Banks really need to provide information to the general public, especially regarding their financial condition which is absolutely related to the high and low level of trust that the community will give to a bank (Rinaldy, 2008). The financial condition and development of a healthy company will reflect efficiency in good performance in the company and capital factors have important meanings (Sasongko, 2004). Banks are also like trading companies, capital is very important for banks to provide credit to their customers, besides that, the amount of assets is also very important. If the amount of bank assets is large then automatically the bank also has good performance (Kurniawati, 2009).

This research was conducted to examine the relationship between the scale of operations as well as capital structure and the operating performance of sharia banks. The scale of operations is proxied by the number of assets, the capital structure is proxied by the ratio of the amount of owned capital compared to liabilities, while the performance of sharia banks is proxied by CAMEL factors.

\section{HYPOTHESIS DEVELOPMENT}

CAMEL (Capital adequacy, Assets quality, Management, Earning, Liquidity) is an aspect that really determine the health of a bank. The five key aspects of determining the soundness of the bank include aspects of capital, quality of productive assets, management, earnings and liquidity.

CAMEL ratio has been determined by the monetary authorities in Indonesia, as stated in PBI No.13/I PBI/2011 on January 5, 2011, Decree of Bank Indonesia Directors Number 13/24/DPNP on October 5 concerning Procedures for Assessing Soundness Levels of Commercial Banks. PBI No. 9/1/ PBI/2007 on January 24, 2007 concerning Sharia Commercial Bank Health Assessment System. PBI no.19/17/2007 on 4 December 2007 concerning the evaluation of Soundness Levels of Rural Banks and PBI No. 9/17/PBI/2007 on 4 December 2007 concerning on Procedures for Soundness Rating of Sharia BPR including CAMEL has been reestab- lished as a measure of commercial bank, BPR and sharia banks, sharia BPR in accordance with these provisions, the bank's soundness is measured by certain criteria and weights.

The sum of the five factors is the total score that determines whether the bank is categorized as healthy or not. Besides being based on quantitative scores, the assessment of bank health predicate is also influenced judgmentally.

Sabir, Ali dan Habbe (2012) examined the effect of bank health ratios on the financial performance of sharia banks and conventional banks in Indonesia, and he found differences in financial performance between sharia banks and national conventional banks in Indonesia. The samples in the study were 4 sharia banks and 4 conventional banks. the Data were analyzed using multiple regression models and different tests. The level of bank health ratios measured by CAR, BOPO, NOM, NPF, FDR, NIM, NPL, and LDR. The results showed that $C A R$ did not significantly influence ROA, BOPO had a negative and significant effect on ROA, NOM had a positive and significant effect on ROA, NPF had no significant effect on ROA, FDR had a positive and significant effect on ROA in sharia banks in Indonesia. CAR has a positive and significant effect on ROA, BOPO has no effect on ROA, NIM has a positive and significant influence on ROA, NPL has a negative and significant effect on ROA, LDR has a negative and significant effect on ROA in conventional banks in Indonesia.

Dewi (2010) researching in sharia banks, found that Capital Adequacy Ratio (CAR) did not significantly influence ROA in sharia banks in Indonesia, Financing to Deposit Ratio (FDR) did not significantly influence ROA in sharia banks in Indonesia. Non-Performing Financing (NPF) has a significant negative effect on ROA in sharia banks in Indonesia, the Operational Efficiency Ratio (REO) has a significant negative effect on ROA in sharia banks in Indonesia.

Trada, Trabelsi and Gouxc (2017), Petriaa, Caprarub, and Ihnatovc (2015), Sabir, Ali dan Habbe (2012), Mahardian (2008) conducted a study showing that the variables of CAR, NIM, and LDR had a positive and significant effect on ROA and BOPO which had a negative and significant effect on ROA. While for the NPL variable, it has a negative influence on ROA, but it is not significant. Of the four significant variables, the BOPO variable has the greatest influence on ROA with a coefficient value of -3.404 . Thus, the bank (issuer) is expected to pay more attention to the level of operating efficiency to increase profitability on its financial per- 
formance. Then the explanation of the insignificance of the NPL variable on ROA is during the study period, the bank intermediation function did not work well.

Haryanto (2016a), Mawardi (2005) also conducted a study showing that the four variables CAR, NPL, BOPO, and NIM affect the performance of commercial banks. For CAR and NIM variables, they have a positive influence on ROA, while $B O P O$ and NPL variables have a negative influence on ROA. Of the four variables, the most influential on ROA is the NIM variable.

The assessment of the performance of public banking companies is very important because the activities of banking companies have a very large influence on the national economy. Several similar studies have been conducted, each of which has sampling characteristics, types of banks and different time conditions.

The measure set by Bank Indonesia to assess the soundness of banks in Indonesia is same as performance measure that is often used to predict bank bankruptcy carried out in bank rating systems in CAMEL capital, which ranks bank performance based on (1) Capital adequacy, (2) Assets quality, (3) Management, (4) Earning, and (5) Liquidity. Capital adequacy in CAMEL model can be analyzed using leverage ratio, or core capital-to-assets ratio.

Whalen and Thomson (1988) used financial data to identify bank conditions. The use of the CAMEL model for analyzing financial data will be useful to identify the health condition of the bank. This model is not fully applicable to published data, such as financial statements. The results of CAMEL model analysis can provide information in classifying commercial banks according to the risk class differences (Whalen and Thomson, 1988, Aldasoro, Cladio and Drehman, 2018).

The use of secondary data to evaluate the performance of banking industry can be justified. Analysis of financial indicators is usually intended as a tool for corporate management decision making in order to achieve the expected goals. The financial indicators in the form of financial ratios can be used as an early warning system for the deterioration of the financial condition of a company. Based on the description above, the alternative hypothesis is proposed as follows:

$\mathrm{H}_{1}$ : There is a significant relationship between increasing scale of operations (total assets of the bank) and the increase in operating performance (Capital Adequacy Ratio (CAR), capital growth, Net Performing Finance (NPF), fi- nancing growth, Return on Assets (ROA), Return on Equity (ROE), profit growth, Finance Deposit Ratio (FDR), growth in third party funds, BOPO, and Net Income (NI)) sharia banks

$\mathrm{H}_{2}$ : There is a significant relationship between the increasing amount of owned capital and the increasing operating performance (Capital Adequacy Ratio (CAR) ratio, capital growth, Net Performing Finance (NPF), financing growth, Return on Assets (ROA), Return on Equity (ROE), profit growth, Finance Deposit Ratio (FDR), growth in third party funds, BOPO, and Net Income (NI)) sharia banks

$\mathrm{H}_{3}$ : There are significant differences in operating performance (Capital Adequacy Ratio (CAR) ratio, capital growth, Net Performing Finance (NPF), financing growth, Return on Assets (ROA), Return on Equity (ROE), profit growth, Finance Deposit Ratio (FDR)), growth of thirdparty funds, BOPO and Net Income (NI)) among groups of sharia banks viewed in terms of the scale of operations and capital structure.

\section{DATA AND METHODS}

This research is empirical research using hypothesis testing, which aims to test hypothetical models. The research data used in the form of secondary data that were historical, namely from the publications of sharia public bank financial statements, sharia units and Islamic BPR in the region of Central Java and Yogyakarta Special Region for one year, in 2015. The financial reporting period in this study used the end of the accounting year period, 31 December.

The data collection method was through literature studies from Indonesian Banking Directory and a site from www.bi.go.id and direct collection of secondary data (financial reports) to the relevant sharia banks. The population in this study was sharia banks registered in Bank Indonesia in 2015. The research samples were taken by purposive sampling (non-probability sampling). It is the selection of samples on population that has been known before using the following criteria:1) Sharia bank is sharia public bank (BUS), sharia business unit (UUS), and sharia BPR in Central Java and Yogyakarta Special Region. 2) Data needed for research is available over a one-year period, in 2015.

The samples used in this study consisted of 15 sharia public banks (Syariah BTPN, BNI Syariah, BRI Syariah, Panin Dubai Syariah, Bank Syariah Mandiri, Bank Muamalat, BCA Syariah, Bukopin 
Syariah, Mega Syariah, Maybank Syariah, Bank Victoria Syariah, CIMB Niaga Syariah, Permata Bank, Danamon Syariah, Syariah Bank Jateng), sharia business unit and 19 Sharia BPRs (BPRS Syariah Cilacap, Sukowati Sragen, BDS Jogja, Artha Surya Barokah Semarang, Buana Mitra Purbalingga Officers, BASS Sampang, Bangun Drajat Bantul Residents, HIKS Solo, Mount Slamet Cilacap, Mitra Mulia Mulia Sleman, Danagung Syariah Sleman, Margiriski Bahagia Bantul, Artha Leksana Banyumas, BAS Banyumas, Artha Amanah Umat Semarang, Mitra Harmoni Yogyakarta, PNM Binama Semarang, Saka Mulia Holy Fund and Ben Salamah Abadi Grobogan) in Central Java and DIY.

The analytical method used in this study is Pearson Product Moment Correlation and OneWay Anova testing. Pearson Product Moment Correlation Test was used to prove the hypothesis of the relationship between two variables in the form of intervals or ratios and the data sources of two or more variables are same. While One-Way Anova test was used to test two or more populations whether they have the same average score or not.

In the analysis of this study, the scale of operations was proxied by the number of bank assets, while the capital structure was the ratio between the amount of owned capital compared to liabilities. The level of bank performance in this study used the proxy of CAMEL factors as a variable measuring bank performance: 1) Capital aspect: this aspect was assessed by CAR (Capital Adequacy Ratio), capital growth, 2) The quality aspect of earning assets was proxied by Net Performing Finance (NPF), Financing Growth, 3) Management: management aspects were proxied by Profit Growth, Third party Fund Growth, BOPO, 4) Rentability: bank profitability was measured by Return on Assets (ROA), Return on Equity (ROE), Net Income (NI), 5) Liquidity: the level of bank liquidity was measured using FDR (Finance Deposit Ratio)

\section{RESULTS}

\section{Pearson Product Moment Correlation Test}

Testing the effect of operation scale on operating performance. Based on the data that has been collected, the tests performed with the results are presented in table 1. Based on table 1, several things can be explained as follows: 1) Six operating performance ratios consisting of financing growth, ROA, ROE, TPF growth, BOPO and NI accept Ha (alternative hypothesis). 2). Five operating performance ratios, namely CAR, Capital Growth, NPF, Profit Growth, FDR, reject Ha (alternative hypothesis).

Generally, it can be concluded that the alternative hypothesis which states that the greater total assets of the bank will have a positive effect on the improvement of supported operating performance. The results of this study support the theory from Subramanyam and Wild (2009) in which total assets have a positive relationship to performance.

In terms of assets, a high level of asset adequacy will provide diversification of assets for banks and can expand so that it can increase the bank profitability which will ultimately improve the bank's performance (Rose, 2002).

Table 1. Testing on the Effect of Operation Scale on Operating Performance

\begin{tabular}{lrrr}
\hline Ratio & Significant Level & Level of Relations & Conclusion \\
\hline CAR & 0.915 & $-0,020$ & Ha is rejected \\
Capital growth & 0.413 & $-0,155$ & Ha is rejected \\
NPF & 0.979 & 0.005 & Ha is rejected \\
Financing growth & 0.006 & 0.406 & Ha is accepted \\
ROA & 0.000 & 0.601 & Ha is accepted \\
ROE & 0.001 & 0,573 & Ha is accepted \\
Profit growth & 0.692 & -0.078 & Ha is rejected \\
FDR & 0.771 & 0,055 & Ha is rejected \\
Deposits growth & 0.010 & 0,462 & Ha is accepted \\
Ratio of BO/PO & 0.002 & $-0,541$ & Ha is accepted \\
NI & 0.000 & 0,666 & Ha is accepted \\
\hline
\end{tabular}

Testing the effect of capital structure on operating performance. Based on the data that has been collected, testing was carried out with the following presented table 2 .

Based on table 2, several things can be explained as follows: 1) Six operating performance ratios consisting of financing growth, $\mathrm{ROA}, \mathrm{ROE}$, TPF growth, BOPO and NI accept Ha (alternative hypothesis). 2) Five ratios namely CAR ratio, Capital growth, NPF, Profit growth, FDR reject Ha (alternative hypothesis).

Overall, it can be concluded that the alterna- 
tive hypothesis which states that the larger capitalstructure will have a positive effect on increasing level of operating performance of the supported banks. Rahim, et al. (2008) at Bank Negara Indonesia (BNI) Sharia shows the result that high capital ratio leading to high performance. The same thing is found in (Al Kayed et al. 2014) they obtained that capital ratio, consumer funding ratios, and size caused increasing performance. Adequate bank capital will close the asset level so that it can improve bank performance. This is due to increasing level of trust from depositors to deposit their funds although the interest rate of third-party fund is lower (Rose, 2002).

Table 2. Testing the Effect of Capital Structure on Bank Operational Performance

\begin{tabular}{lccl}
\hline Ratio & Significant Level & Level of Relations & Conclusion \\
\hline CAR & 0.536 & 0.118 & Ha is rejected \\
Core capital growth & 0.455 & -0.142 & Ha is rejected \\
NPF & 0.871 & -0.031 & Ha is rejected \\
Financing growth & 0.026 & 0.406 & Ha is accepted \\
ROA & 0.002 & 0.537 & Ha is accepted \\
ROE & 0.001 & 0.587 & Ha is accepted \\
Profit growth & 0.824 & -0.042 & Ha is rejected \\
FDR & 0.533 & 0.119 & Ha is rejected \\
Deposits growth & 0.031 & 0.395 & Ha is accepted \\
Ratio of BO/PO & 0.006 & -0.491 & Ha is accepted \\
NI & 0.001 & 0.584 & Ha is accepted \\
\hline
\end{tabular}

\section{One-Way Anova Test}

Based on the data that has been collected, testing was carried out with the following results table 3. Based on table 3, several things can be explained as follows: 1) Six operating performance ratios consisting of CAR, capital growth, NPF profit growth, FDR and NI reject the alternative hypothesis (Ha). 2) Five operating performance ratios consisting of financing growth, ROA, ROE, Growth of Third-Party Funds and BOPO accept alternative hypothesis (Ha). Generally, it was concluded that the alternative hypothesis which states that there are different levels of operating performance among groups of sharia banks in terms of the scale of operations and capital structures was unsupported. This is very contrary to what the Financial Services Authority (OJK) has done in which the intensity of supervision is still concentrated in commercial banks compared to BPR because the scale of operation of commercial banks is greater than the scale of BPR operations (www.ojk.go.id).

Table 3. Differential Test on Bank Operational Performance among bank groupsin terms of Total Assets and Capital Structure

\begin{tabular}{lccl}
\hline Ratio & F Observe & F Table & Conclusion \\
\hline CAR & 0.182 & 2.38 & Ha is rejected \\
Core capital growth & 0.792 & 2.38 & Ha is rejected \\
NPF & 0.922 & 2.38 & Ha is rejected \\
Financing growth & 4.957 & 2.38 & Ha is accepted \\
ROA & 6.899 & 2.38 & Ha is accepted \\
ROE & 21.64 & 2.38 & Ha is accepted \\
Profit growth & 0.288 & 2.38 & Ha is rejected \\
FDR & 1.831 & 2.38 & Ha is rejected \\
Deposits growth & 7.407 & 2.38 & Ha is accepted \\
Ratio of BO/PO & 9.177 & 2.38 & Ha is accepted \\
NI & 1.950 & 2.38 & Ha is rejected \\
\hline
\end{tabular}

\section{DISCUSSION}

Based on the results of the analysis show that the scale of operations has no impact on operating performance for capital capital aspects (CAR, capi tal growth). This shows that the scale of the bank's operations is increasing, so the bank's assets will also increase. Increasing the scale of bank operations indicates that the bank is getting bigger. The bigger the bank, the greater the bank's equity. Increased bank equity, also followed by an increase in company size, the increase in bank operations has 
no impact on bank capital (CAR). The results of this study are not supported the research findings of Haryanto (2016b), Margaretha and Letty (2017).

The results of the analysis show that increasing the scale of operations has no effect on the level of risk financing (NPF). Increasing the scale of operations of sharia bank indicates an increase in financing by sharia bank. This shows that the increase in financing made by sharia bank is still followed by good financing management. In addition, financing sharia bank with profit sharing systems can reduce the risk of financing. NPF sharia bank are not caused by the size of the financing made by Islamic banks, but rather how Islamic banks manage and analyze their financing. The findings of this study are supported the research of Firmansyah (2014), Riyadi, Iqbal and Lauren (2014).

The scale of operations of sharia bank has a positive impact on bank performance, financing growth, and bank profitability. Increasing bank operations will certainly increase financing by sharia bank. The increase in financing that sharia bank can make has a positive impact on bank profitability. The results of this study are supported the findings of Haryanto (2016a). In addition, increasing the scale of bank operations has an effect on efficiency. The bigger the bank, the higher the bank's efficiency. This shows the scale of economics in the operations of Islamic banks.

The results showed that the capital structure had no effect on CAR, Core capital growth and risk (NPF). The structure of bank funding is predominantly derived from deposits, so that the bank's capital structure does not affect CAR, Core capital growth and risk (NPF). Sharia bank debt, in the source structure and the bank is relatively small. Islamic banks rely more on funding from deposit. So that the capital structure does not have an impact on CAR, Core capital growth and risk (NPF). But the capital structure has an impact on profitability. Increased debt made by banks can be used for investment, so that it will be able to encourage the profitability of the bank.

Capital structure does not affect the financing provided by sharia bank. sharia bankas intermediary institutions, the source and funding comes from deposits. Debt is not used as a source of financing, even though the size of the capital structure does not affect financing.

The results showed that there was no difference between CAR, core capital growth, NPF, profit growth, FDR and Net income (NI) between banks with large and small scale. While financing growth, profitability, FDR, TPF growth and efficiency. Lar- ge banks tend to have a greater market reach, so that they will be able to raise funds and finance the bigger ones. Banks with greater assets will tend to be able to use the economies of scale, making them more efficient. high This has an impact on bank profitability.

\section{CONCLUSION AND SUGESTION}

Based on the data analysis and discussion that has been carried out, it can be concluded that larger the scale of operations and capital structure will positively impact on the increasing performance of sharia banks and sharia BPR. In addition, there is no difference in bank operating performance between sharia bank groups in terms of scale of operations and capital structure. Sharia banks with small scale assets and capital structures also require equal treatment from the Financial Services Authority, so that there should be no discrimination in terms of banking development and supervision.

\section{REFERENCES}

Aldasoro, I., Cladio B.C. and Drehman, M. (2018). Early Warning Indicators of Banking Crises: Expanding The Family. BIS Quarterly Review, March: 29-45.

Al Kayed, T.L., Zain, S.T.R.S.M., Duasa, J. (2014). The Relationship between Capital Structure and Performance of Islamic Banks. Journal of Islamic Accounting and Business Research.5

Ardiansyah, M., Qizam, I., dan Setyono J. (2013). Konstruksi Kopetensi Profesional Sarjana Ekonomi Syariah pada Lembaga Keuangan Syariah. Jurnal Penelitian Sosial Keagamaan. $7(1)$

Firmansyah, I. (2014). Determinant of Non Performing Loan: The Case of Islamic Bank In Indonesia. Buletin Ekonomi Moneter dan Perbankan. 17(2)

Haryanto, S. (2016a). Profitability Identification of National Banking Through Credit, Capital, Capital Structure, Eficiency, and Risk Level. Jurnal Dinamika Manajemen. 7 (1): 11-21

Haryanto, S. (2016b). Determinan Permodalan bank Melalui Profitabilitas, Risko, Ukuran Perusahaan, Efisiensi dan Struktur Modal. Jurnal Ekonomi dan Bisnis. 19(1): 117-136

Kurniawati, E. (2009). Pengaruh Skala Operasi dan Struktur Modal terhadap Kinerja Operasi 
Perbankan yang Terdaftar di Bursa Efek Indonesia. Skripsi. Universitas Muhammadiyah Surakarta.

Mahardian, P. (2008). Analisis Pengaruh Rasio CAR, BOPO, NPL, NIM dan LDR Terhadap Kinerja Keuangan Perbankan (Studi Kasus Perusahaan Perbankan yang Tercatat di BEJ Periode Juni 2002-Juni 2007. Tesis. Universitas Diponegoro.

Margaretha, Farah, Letty. (2017). Faktor-Faktor Yang Mempengaruhi Kinerja Keuangan Perbankan Indonesia. Jakarta: Universitas Trisakti. $6(2)$.

Mawardi, W., (2005). Analisis Faktor-faktorYang Mempengaruhi Kinerja Keuangan Bank Umum di Indonesia (Studi Kasus Pada Bank Umum DenganTotal Assets Kurang Dari 1 Triliun). Jurnal Bisnis dan Strategi. 14(1).

Mu'allim, A. (2003). Persepsi Masyarakat terhadap Lembaga Keuangan Syariah. Al-Mawarid. Edisi 3. Yogyakarta.

Petriaa, N., Caprarub, B. and Ihnatovc, L. (2015). Determinants of Banks' Profitability: Evidence from EU 27 Banking Systems. 7th International Conference on Globalization and Higher Education in Economics and Business Administration, GEBA 2013. Procedia Economics and Finance. 20: 518-524.

Remy, S. (1999). Perbankan Islam dan Kedudukannya dalam Tata Hukum Perbankan Indonesia. Jakarta: Pustaka Utama Grafiti.

Rinaldy, E. (2008). Manajemen Lembaga Keuangan. Jakarta: Kencana.

Riyadi, S., Iqbal, M. dan Lauren, N. (2014). Strategi Pengelolaan No Performaning Loan Bank Umum yang Go Public. JDM Jurnal Dinamika Manajemen. 6(1): 84-96.

Rose, P. S. (2002). Commercial Bank Management. New York: Mc Graw-Hill. International Edition.

Sabir, M., Ali, M., dan Habbe, A., H. (2012). Pengaruh Rasio Kesehatan Bank Terhadap Kinerja Keuangan Bank Umum Syariah Dan Bank Konvensional di Indonesia. Jurnal Analisis.1(1).

Sancoko. (2012). Analisa Perbandingan Konsentrasi antara Perbankan Syariah dan Perbankan Konvensional. Jurnal Administrasi Terapan. 10(1).
Setiawan dan Sari, R., M. (2018). Rentabilitas Bank Umum Syariah Sesudah Spin-Off berdasarkan Tipe Pemisahannya di Indonesia. Amwaluna. 2(1)

Subramanyam, K. R., dan Wild, J. J. (2009). Financial Statement Analysis. Singapore: Mc GrawHill. Tenth Edition.

Syafrida, I. dan Aminah, I. (2015). Faktor Perlambatan Pertumbuhan Bank Syariah di Indonesia dan Upaya Penanganannya. Jurnal Ekonomi dan Bisnis. 14(1)

Trada, N., Trabelsi, M.A., and Gouxc, J.F. (2017). Risk and Profitability of Islamic Banks: A Religious Deception or an Alternative Solution? European Research on Management and Business Economics. 23: 40-45.

Whalen, G. dan Thomson, J., B. (1988). Using Financial Data to Identify Changes in Bank Condition. http://clevelandfed.org/research/ review

Yulianto. (2018). Pengaruh Literasi Keuangan Syariah Terhadap Keputusan Penggunaan Produk atau Layanan Lembaga Keuangan Syariah. Skripsi. Universitas Islam Indonesia.

www.ojk.go.id 